Article

\title{
An Alternative Process for Leaching Chalcopyrite Concentrate in Nitrate-Acid-Seawater Media with Oxidant Recovery
}

\author{
César I. Castellón ${ }^{1}{ }^{\mathbb{D}}$, Pía C. Hernández ${ }^{1} \mathbb{D}$, Lilian Velásquez-Yévenes ${ }^{2}{ }^{\mathbb{D}}$ and \\ María E. Taboada ${ }^{1, *}$ \\ 1 Departamento de Ingeniería Química y Procesos de Minerales, Facultad de Ingeniería, \\ Universidad de Antofagasta, Av. Angamos 601, Antofagasta 1240000, Chile \\ 2 Escuela de Ingeniería Civil de Minas, Facultad de Ingeniería, Universidad de Talca, Curicó 3340000, Chile \\ * Correspondence: mariaelisa.taboada@uantof.cl; Tel.: +56-55-637345
}

Received: 28 January 2020; Accepted: 14 April 2020; Published: 17 April 2020

check for updates

\begin{abstract}
An alternative copper concentrate leaching process using sodium nitrate and sulfuric acid diluted in seawater followed by gas scrubbing to recover the sodium nitrate has been evaluated. The work involved leaching test carried out under various condition by varying temperature, leaching time, particle size, and concentrations of $\mathrm{NaNO}_{3}$ and $\mathrm{H}_{2} \mathrm{SO}_{4}$. The amount of copper extracted from the chalcopyrite concentrate leached with seawater, $0.5 \mathrm{M}_{6}$ of $\mathrm{H}_{2} \mathrm{SO}_{4}$ and $0.5 \mathrm{M}$ of $\mathrm{NaNO}_{3}$ increased from $78 \%$ at room temperature to $91 \%$ at $45{ }^{\circ} \mathrm{C}$ in $96 \mathrm{~h}$ and $46 \mathrm{~h}$ of leaching, respectively. Gas scrubbing with the alkaline solution of $\mathrm{NaOH}$ was explored to recover part of the sodium nitrate. The dissolved salts were recovered by evaporation as sodium nitrate and sodium nitrite crystals.
\end{abstract}

Keywords: chalcopyrite; leaching; nitrate; seawater; gas scrubbing

\section{Introduction}

Chilean mining is facing a shortage of water resources, depletion of copper oxide ores and those containing secondary sulfide copper. This depletion will leave chalcopyrite ores as the main source of copper for future plants. To assure sustainable production alternative extractive methods must be developed.

Chalcopyrite $\left(\mathrm{CuFeS}_{2}\right)$ is the most important copper sulfide mineral, representing approximately $70 \%$ of the world's known copper reserves [1]. Chalcopyrite is normally associated with pyrite $\left(\mathrm{FeS}_{2}\right)$, bornite $\left(\mathrm{Cu}_{5} \mathrm{FeS}_{4}\right)$, sphalerite $(\mathrm{ZnS})$, chalcocite $\left(\mathrm{Cu}_{2} \mathrm{~S}\right)$, covellite $(\mathrm{CuS})$, enargite $\left(\mathrm{Cu}_{3} \mathrm{AsS}_{4}\right)$ or molybdenite $\left(\mathrm{MoS}_{2}\right)$. The extractive metallurgy of chalcopyrite is based largely on a traditional route involving comminution and flotation, smelting and electrorefining, representing around the $85 \%$ of the copper production in Chile [2]. Environmental, financial and technical disadvantages of these processes have drawn attention to hydrometallurgy methods as an alternative. The main problem for treating chalcopyrite by a hydrometallurgy route is its refractoriness. This refractoriness is due to the formation of a passivating layer on the surface of chalcopyrite that inhibits the contact of mineral with oxidizing agents, reducing the dissolution rate. It is well known that the dissolution of chalcopyrite is a potential-dependent reaction and many studies have been carried out to elucidate the relationship between the solution potential and this passivating layer [2,3].

Several studies have been carried out in order to increase the dissolution rate of chalcopyrite, including: (i) leaching with strong oxidizing agents [4], (ii) leaching under high pressure and temperature [5], (iii) bacterial leaching [6], (iv) chloride media [2,3,7] and nitrate/nitrite media [8].

There is a considerable body of published information on the dissolution of chalcopyrite in sulfate and chloride media. Most of this literature reports that the dissolution of chalcopyrite is more effective 
in chloride media due to the greater reactivity of sulfide minerals in this medium. Seawater is then presented as an alternative source of chloride ions [9-13].

Sodium nitrate in an acid medium provides an option for possible leaching of many sulfide minerals, including chalcopyrite, at an acceptable kinetic rate due to the high proton activity created by the presence of sodium nitrate, and a strong oxidizing agent [14]. Sodium nitrate has been used as an oxidizing agent for more than 130 years [15]. However, these applications involve high temperatures and high levels of pressure. The main advantages of using nitrate ions in acidic leaching are: (i) nitrate is a strong oxidizing agent to decompose sulfides (Reaction (1)), (ii) the gases produced $\left(\mathrm{NO}_{\mathrm{x}}\right.$ ) can easily be scrubbed, and (iii) scrubbed $\mathrm{NaNO}_{3}$ can be recycled $[8,16,17]$ :

$$
\mathrm{NO}_{3}^{-}+4 \mathrm{H}^{+}+3 e^{-} \rightarrow \mathrm{NO}_{(g)}+2 \mathrm{H}_{2} \mathrm{O} \quad \mathrm{E}^{\circ}=0.96 \mathrm{~V}
$$

Several authors have investigated the possible leaching reactions by considering select elements, ions, solid phases, and gas products [16,18-20]. Sokić et al. [16] proposed the most thermodynamically favorable overall reaction (Reaction (2)) for chalcopyrite dissolution in the $\mathrm{CuFeS}_{2}-\mathrm{NaNO}_{3}-\mathrm{H}_{2} \mathrm{SO}_{4}-\mathrm{H}_{2} \mathrm{O}$ system:

$$
\mathrm{C}_{u} \mathrm{~F}_{e} \mathrm{~S}_{2}+4 \mathrm{~N}_{a} \mathrm{NO}_{3}+4 \mathrm{H}_{2} \mathrm{SO}_{4} \rightarrow \mathrm{C}_{u} \mathrm{SO}_{4}+\mathrm{F}_{e} \mathrm{SO}_{4}+2 \mathrm{~N}_{a 2} \mathrm{~S}_{\mathrm{O}}+4 \mathrm{NO}_{2(g)}+2 \mathrm{~S}^{\circ}+4 \mathrm{H}_{2} \mathrm{O}
$$

Reaction (2) is accompanied by several secondary reactions shown by Reactions (3) to (8). Oxidative leaching of a chalcopyrite concentrate in an acid medium using nitrate as an oxidizing agent generates elemental sulfur $[16,18,21]$. The solution creates a strong oxidizing environment, as shown in Reaction (5):

$$
\begin{aligned}
\mathrm{FeSO}_{4}+\frac{1}{3} \mathrm{NaNO}_{3}+\frac{2}{3} \mathrm{H}_{2} \mathrm{SO}_{4} \rightarrow \frac{1}{2} \mathrm{Fe}_{2}\left(\mathrm{SO}_{4}\right)_{3}+\frac{1}{6} \mathrm{Na}_{2} \mathrm{SO}_{4}+\frac{1}{3} \mathrm{NO}+\frac{2}{3} \mathrm{H}_{2} \mathrm{O} \\
\mathrm{CuFeS} \mathrm{S}_{2}+2 \mathrm{Fe}_{2}\left(\mathrm{SO}_{4}\right)_{3} \rightarrow \mathrm{CuSO}_{4}+5 \mathrm{FeSO}_{4}+2 \mathrm{~S}^{\circ} \\
3 \mathrm{NO}_{2(g)}+\mathrm{H}_{2} \mathrm{O} \rightarrow 2 \mathrm{HNO}_{3}+\mathrm{NO}_{(g)} \\
\mathrm{NO}_{(g)}+2 \mathrm{NaNO}_{3}+\mathrm{H}_{2} \mathrm{SO}_{4} \rightarrow 3 \mathrm{NO}_{2(g)}+\mathrm{Na}_{2} \mathrm{SO}_{4}+\mathrm{H}_{2} \mathrm{O}
\end{aligned}
$$

Sulfur, produced in reactions (2) or/and (4) is then oxidized to sulfate in a sodium nitrate medium, according to reactions (7) and (8). At room temperature, anhydrous sodium sulfate crystallizes [22,23], as shown in Reaction (7):

$$
\begin{gathered}
\mathrm{S}^{\circ}+2 \mathrm{NaNO}_{3} \rightarrow \mathrm{Na}_{2} \mathrm{SO}_{4}+2 \mathrm{NO}_{(g)} \\
S^{\circ}+3 \mathrm{NO}_{2(g)}+\mathrm{H}_{2} \mathrm{O} \rightarrow \mathrm{H}_{2} \mathrm{SO}_{4}+3 \mathrm{NO}_{(g)}
\end{gathered}
$$

The thermodynamic feasibility of these reactions at atmospheric condition at $298 \mathrm{~K}$ and $318 \mathrm{~K}$ was estimated from standard Gibbs free energy calculations based on HSC Chemistry software V9 as shown in Table 1 (calculated data are based on the thermodynamic values of $\Delta \mathrm{G}^{\circ}, \Delta \mathrm{S}^{\circ}$, and $\Delta \mathrm{H}^{\circ}$, of the chemical elements and their compounds). These calculations show that almost all reactions predict negative Gibbs energy values, which clearly indicates they are all thermodynamically favorable under the given conditions, except for Reaction (5). Reaction (2) is more favorable than Reaction (4) under the same conditions.

According to the reactions shown previously the leaching of chalcopyrite in acidic sodium nitrate solution and at high temperature produces notable amounts of gaseous nitrogen oxide gases or $\mathrm{NO}_{\mathrm{x}}$. These gases are a source of serious environmental problems, therefore, their treatment is mandatory. 
Table 1. Standard Gibbs free energies for the $\mathrm{CuFeS}_{2}-\mathrm{H}_{2} \mathrm{SO}_{4}-\mathrm{NaNO}_{3}-\mathrm{H}_{2} \mathrm{O}$ system at $298 \mathrm{~K}$ and $318 \mathrm{~K}$ (reactions taken Sokić et al. [16] and values corrected using HSC 9.0).

\begin{tabular}{ccc}
\hline Reaction $\mathbf{N}^{\circ}$ & $\Delta \mathbf{G}^{\circ}{ }_{\mathbf{2 9 8} \mathbf{K}} \mathbf{( k J / m o l )}$ & $\Delta \mathbf{G}^{\circ}{ }_{\mathbf{3 1 8} \mathbf{K}}(\mathbf{k J} / \mathbf{m o l})$ \\
\hline$(2)$ & -349.1 & -361.4 \\
$(3)$ & -66.0 & -66.6 \\
$(4)$ & -62.9 & -63.8 \\
$(5)$ & 8.7 & 14.1 \\
$(6)$ & -16.7 & -23.5 \\
$(7)$ & -363.2 & -369.3 \\
$(8)$ & -346.5 & -345.8 \\
\hline
\end{tabular}

Suchak and Joshi [24] stated that scrubbing $\mathrm{NO}_{\mathrm{x}}$ gases is a complex process controlled by mass transfer limitations and involving bulk gas, gas film, interface, liquid film and bulk liquid mechanisms. Other factors that have been reported to affect the overall scrubbing rate and selectivity are temperature, pressure, the composition of $\mathrm{NO}_{\mathrm{x}}$ gas, and the partial pressures of oxygen and water in the gas phase [25-30]. In the aerated leaching process, the nitrate ion is reduced to nitrogen oxide gas, $\mathrm{NO}_{(\mathrm{g})}$, then the $\mathrm{NO}_{(\mathrm{g})}$ is oxidized rapidly (in less than $0.1 \mathrm{~s}$ ) in the gas phase to nitrogen dioxide, $\mathrm{NO}_{2(\mathrm{~g})}$. Sodium nitrate $\left(\mathrm{NaNO}_{3}\right)$ and sodium nitrite $\left(\mathrm{NaNO}_{2}\right)$ can then be regenerated by bubbling nitrous oxide gas in a dilute solution of sodium hydroxide $(\mathrm{NaOH})$, which can then be crystallized and reused in the leaching stage.

The $\mathrm{NO}_{x}$ gas released from an acidic leaching contains several nitrogen oxides, mainly $\mathrm{NO}, \mathrm{NO}_{2}$, $\mathrm{N}_{2} \mathrm{O}_{3}$ and $\mathrm{N}_{2} \mathrm{O}_{4}$. The most important reactions are showed from reactions (9)-(11):

$$
\begin{gathered}
2 \mathrm{NO}_{(g)}+\mathrm{O}_{2(g)} \rightarrow 2 \mathrm{NO}_{2(g)} \\
2 \mathrm{NO}_{2(g)} \rightarrow \mathrm{N}_{2} \mathrm{O}_{4(g)} \\
\mathrm{NO}_{(g)}+\mathrm{NO}_{2(g)} \rightarrow \mathrm{N}_{2} \mathrm{O}_{3(g)}
\end{gathered}
$$

When $\mathrm{NO}_{\mathrm{x}}$ is in contact with an alkaline solution of $\mathrm{NaOH}$, it forms nitrite and nitrate ions. The liquid phase reactions are presented from reaction (12) to (14). The nitrogen oxides $\left(\mathrm{NO}_{2}, \mathrm{~N}_{2} \mathrm{O}_{3}\right.$, and $\mathrm{N}_{2} \mathrm{O}_{4}$ ) are scrubbed in the liquid film phase [31] but the selectivity is poor which leads to the formation of a mixture of nitrite and nitrate ions [29]. According to Suchak et al. [29] chemical reactions (12) to (14) show that $\mathrm{NaNO}_{2}$ is more selective than $\mathrm{NaNO}_{3}$ and $\mathrm{NO}_{2}$ (g) captured in the aqueous solution is generally produced through disproportionation reactions:

$$
\begin{gathered}
2 \mathrm{NO}_{2(g)}+2 \mathrm{NaOH}_{(a q)} \rightarrow \mathrm{NaNO}_{3(a q)}+\mathrm{NaNO}_{2(a q)}+\mathrm{H}_{2} \mathrm{O}_{(a q)} \\
\mathrm{N}_{2} \mathrm{O}_{4(g)}+2 \mathrm{NaOH}_{(a q)} \rightarrow \mathrm{NaNO}_{3(a q)}+\mathrm{NaNO}_{2(a q)}+\mathrm{H}_{2} \mathrm{O}_{(a q)} \\
\mathrm{N}_{2} \mathrm{O}_{3(g)}+2 \mathrm{NaOH}_{(a q)} \rightarrow 2 \mathrm{NaNO}_{2(a q)}+\mathrm{H}_{2} \mathrm{O}_{(a q)}
\end{gathered}
$$

The oxidation of $\mathrm{NO}$, the formation in the gas phase of $\mathrm{N}_{2} \mathrm{O}_{3}$ and $\mathrm{N}_{2} \mathrm{O}_{4}$, and the scrubbing of $\mathrm{NO}_{2}, \mathrm{~N}_{2} \mathrm{O}_{3}$ and $\mathrm{N}_{2} \mathrm{O}_{4}$ in the liquid phase are all exothermic reactions. Thus, their equilibria shift to the right as temperature decreases. The gas dispersion rate has a significant effect on kinetics, and smaller bubbles provide a better contact with the alkaline scrubbing solution. Table 2 shows several reactions and related enthalpies calculated using HSC Chemistry Software V.9.0 (Outokumpu Research Oy, Helsinki, Finland).

The most effective methods to scrub $\mathrm{NO}_{x}$ are using urea + nitric acid [32], using ammonium bisulfate [33] and using sodium hydroxide as the scrubbing solution.

This paper proposes a feasible process to leach chalcopyrite concentrate with a mixture of sodium nitrate and diluted sulfuric acid dissolved in seawater as a source of chloride ions at atmospheric pressure and moderate temperature $\left(\leq 45^{\circ} \mathrm{C}\right)$. Due to its low cost the process includes a scrubbing 
stage using $\mathrm{NaOH}$ to capture $\mathrm{NO}_{x}$ gases that could enhance the formation of $\mathrm{NaNO}_{x}$ salt (or a mixture of $\mathrm{NaNO}_{3}$ and $\mathrm{NaNO}_{2}$ ), the $\mathrm{NaNO}_{x}$ (oxidants) can be recovered by crystallization and reused again as the leaching process oxidants.

Table 2. Thermodynamic data for gas and liquid phase reactions (reactions taken Suchak et al. [15] and values corrected using HSC V.9.0).

\begin{tabular}{ccc}
\hline Reaction $\mathbf{N}^{\circ}$ & $\mathbf{\Delta}_{\mathbf{H}^{\circ}}{ }_{\mathbf{2 9 8} \mathbf{K}} \mathbf{( \mathbf { k J } / \mathbf { m o l } )}$ & $\mathbf{\Delta G}_{\mathbf{2 9 8} \mathbf{K}} \mathbf{( \mathbf { k J } / \mathbf { m o l } )}$ \\
\hline$(9)$ & -114.5 & -70.9 \\
$(10)$ & -56.9 & -4.5 \\
$(11)$ & -40.5 & 1.9 \\
$(12)$ & -204.6 & -171.0 \\
$(13)$ & -147.7 & -166.6 \\
$(14)$ & -118.6 & -129.3 \\
\hline
\end{tabular}

\section{Materials and Methods}

\subsection{Chalcopyrite Concentrate and Reagents}

The chalcopyrite concentrate sample was supplied by a Chilean mining company. Two particle sizes were used with $\mathrm{P}_{80}$ of 29.8 and $60.66 \mu \mathrm{m}$, respectively. The particle sizes distributions were determined using a Microtrac model S3500 laser diffraction Particle Size Analyser (PSA) (Verder Scientific, Newtown, PA, USA). The chemical composition was determined by digestion which was then analyzed using inductively coupled plasma atomic emission spectroscopy (ICP-AES, ICPE-9000, Shimadzu, Tokyo, Japan). The mineralogical characterization was determined by quantitative evaluation of the minerals by scanning electron microscopy (QEMSCAN) and morphology of the samples were determined by Scanning Electron Microscopy (SEM), equipped with a microscope-coupled X-ray dispersive energy analyzer, SEM-EDX (model JSM 6360 LV, JEOL Ltd., Tokyo, Japan). Table 3 shows the chemical analysis and mineralogical composition of the concentrate sample. Chemical analysis showed that the concentrate included mostly $\mathrm{Cu}, \mathrm{Fe}$ and S. The XRD pattern (Siemens D5000 X-ray diffractometer, Bruker, Billerica, MA, USA) shows that the sample was mainly composed of chalcopyrite and pyrite, with small amounts of covellite and chalcanthite. Based on this data, the sample is composed of $63 \%$ of copper sulfides, following by $24.3 \%$ of other sulphides.

Table 3. Chemical and mineralogical analysis of the chalcopyrite concentrate.

\begin{tabular}{|c|c|c|c|c|}
\hline \multicolumn{2}{|c|}{ Chemical Analysis } & \multicolumn{3}{|c|}{ Mineralogical Analysis } \\
\hline Element & wt. $\%$ & Minerals & Formula & wt. $\%$ \\
\hline $\mathrm{Si}$ & 2.3 & Quartz & $\mathrm{SiO}_{2}$ & 2.2 \\
\hline $\mathrm{Fe}$ & 32.7 & Pyrite & $\mathrm{FeS}_{2}$ & 23.3 \\
\hline $\mathrm{Al}$ & 1.0 & Chalcopyrite & $\mathrm{CuFeS}_{2}$ & 61.5 \\
\hline $\mathrm{Mg}$ & 0.2 & Covellite & $\mathrm{CuS}$ & 1.5 \\
\hline $\mathrm{Ca}$ & 0.3 & Molybdenite & $\mathrm{MoS}_{2}$ & 0.4 \\
\hline $\mathrm{Cu}$ & 25.0 & Dolomite & $\mathrm{CaMg}\left(\mathrm{CO}_{3}\right)_{2}$ & 1.4 \\
\hline $\mathrm{Zn}$ & 0.5 & Boehmite & $\mathrm{AlOOH}$ & 2.0 \\
\hline $\mathrm{Ti}$ & 0.5 & Chalcanthite & $\mathrm{CuSO}_{4} \cdot 5 \mathrm{H}_{2} \mathrm{O}$ & 1.2 \\
\hline Mo & 0.2 & Albite & $\mathrm{NaAlSi}_{3} \mathrm{O}_{8}$ & 2.2 \\
\hline K & 0.4 & Muscovite & $\mathrm{KAl}_{2}\left(\mathrm{Si}_{3} \mathrm{Al}\right) \mathrm{O}_{10}(\mathrm{OH})_{2}$ & 1.9 \\
\hline $\mathrm{C}$ & 0.2 & Biotite & $\mathrm{K}\left(\mathrm{Mg}, \mathrm{Fe}^{2+}\right)_{3}\left(\mathrm{Si}_{3} \mathrm{Al}\right) \mathrm{O}_{10}(\mathrm{OH})_{2}$ & 0.7 \\
\hline $\mathrm{Na}$ & 0.3 & Sphalerite & $\left(\mathrm{Zn}_{\mathrm{x}}, \mathrm{Fe}_{1-\mathrm{x}}\right) \mathrm{S}$ & 0.6 \\
\hline \multirow[t]{2}{*}{ S } & 36.3 & Gypsum & $\mathrm{CaSO}_{4} \cdot 2 \mathrm{H}_{2} \mathrm{O}$ & 0.8 \\
\hline & & Clinochlore & $\left(\mathrm{Mg}, \mathrm{Fe}^{2+}\right)_{5} \mathrm{Al}\left(\mathrm{Si}_{3} \mathrm{Al}\right) \mathrm{O}_{10}(\mathrm{OH})_{8}$ & 0.2 \\
\hline
\end{tabular}


Sodium nitrate (99.5\% absolute, Merck, Darmstadt, Germany) and sulfuric acid (95-97\%, Merck, Darmstadt, Germany) were used in the leaching tests. The scrubbing solution was prepared with $\mathrm{NaOH}$ (99.0\% absolute, Merck, Darmstadt, Germany) and distilled water.

Seawater was used as source of water and chloride ions in all experiments. It was collected from the coast in San Jorge Bay (Antofagasta, Chile). The sample of seawater was passed through a quartz sand filter $(50 \mu \mathrm{m})$ and a mechanical polyethylene filter $(1 \mu \mathrm{m})$ to remove insoluble particulate matter. Table 4 shows the composition of the seawater, which was obtained by different analytical techniques (argentometric method, atomic absorption spectrometry-AAS and volumetric analysis).

Table 4. Major composition of seawater from San Jorge Bay, Chile.

\begin{tabular}{lcc}
\hline Ion & Concentration $[\mathrm{mg} / \mathrm{L}]$ & Method of Analysis \\
\hline $\mathrm{Na}^{+}$ & 9950 & Atomic absorption spectrometry \\
$\mathrm{Mg}^{2+}$ & 1250 & Atomic absorption spectrometry \\
$\mathrm{Ca}^{2+}$ & 400 & Atomic absorption spectrometry \\
$\mathrm{K}^{+}$ & 380 & Atomic absorption spectrometry \\
$\mathrm{Cl}^{-}$ & 19,450 & Argentometric method \\
$\mathrm{HCO}_{3}^{-}$ & 150 & Acid-base volumetry \\
\hline
\end{tabular}

\subsection{Experimental Procedure}

The experimental test work was carried out in three stages. The first stage was the leaching of chalcopyrite concentrate. A Taguchi L6 $\left(2^{3}\right)$ orthogonal array design experimental setup was employed in Series I to clarify the effects of sulfuric acid and nitrate concentration and a Taguchi L4 $\left(2^{2}\right)$ orthogonal array in Series II for temperature and particle size on copper extraction. Leaching experiments were performed in $2 \mathrm{~L}$ jacketed glass reactors. Each reactor was loaded with $1 \mathrm{~L}$ of leaching solution $(0.1,0.5$ and $1.0 \mathrm{M}$ of sulfuric acid 0.1 and $0.5 \mathrm{M}$ of sodium nitrate and seawater as the source of water and chloride ions). Once the solution reached the desired temperature (room and $45^{\circ} \mathrm{C}$ ), $50 \mathrm{~g}$ of solid sample ( $\mathrm{P}_{80}$ of 29.8 and $\left.60.66 \mu \mathrm{m}\right)$ was added to the reactor.

The pulp was stirred to a homogenous mix with a propeller at a rotation speed of $450 \mathrm{rpm}$. A 10-mL aliquot of the leached solution was withdrawn periodically during the test and analyzed for $\mathrm{Cu}$ and Fe using the atomic absorption spectrometry (AAS method, model 2380, Perkin Elmer, Wellesley, MA, USA). Redox potential (ORP) and $\mathrm{pH}$ were measured throughout the test with a portable meter (model HI991003, Hanna, St. Louis, MO, USA). All experiments were conducted in duplicate. The solid residues were carefully filtered, washed with distilled water, dried at $60{ }^{\circ} \mathrm{C}$ and samples were taken for mineralogical characterization and particle size determination.

The second stage was the alkaline gas scrubbing of $\mathrm{NO}_{x}$ produced in the leaching stage at $45^{\circ} \mathrm{C}$ (Test 9 , see Table 5). At this temperature, enough $\mathrm{NO}_{x}$ gases were produced. Scrubbing was conducted in duplicate using a $1.0 \mathrm{M}$ sodium hydroxide solution. The initial $\mathrm{pH}$ of the scrubbing solution was 13 . The gas was transported to the scrubber by pumping air to the reactor through a tube. The scrubber column was $25 \mathrm{~cm}$ high, the volume of the absorbing solution was $250 \mathrm{~mL}$, and air was supplied at the rate of $3.0 \mathrm{~L} / \mathrm{min}$. The flue gases were dispersed into the solution using a fritted bubble disperser. The bubble size of the dispersed gas was generally $>1 \mathrm{~mm}$. All scrubbing tests were carried out at $2{ }^{\circ} \mathrm{C}$. Figure 1 shows the schematic diagram of leaching and scrubbing tests. The amounts of $\mathrm{NaNO}_{2}-\mathrm{NaNO}_{3}$ and $\mathrm{NaOH}$ salt formation produced from the scrubbing solution were obtained by chemical analysis and ionic balance using atomic absorption spectrometry (AAS), volumetric analysis and colorimetric assays.

Last stage of the work was the recovery of nitrate-nitrite salts by evaporation. The scrubbing solution was dried at $100{ }^{\circ} \mathrm{C}$ to determine the amount of salts that crystallized with the evaporating solvent. Thermal stability was studied from crystallized solids. Nitrite-nitrate salts were characterized by differential scanning calorimetry using a Mettler Toledo TGA/DSC 1 StarSystem, (NETZSCH, Bavaria, Germany). A $10 \mathrm{mg}$ sample was used in the TGA/DSC determinations. This equipment can 
measure the heat capacity of a sample to determine the melting temperature and quantify the degree of crystallinity and characterization of the material.

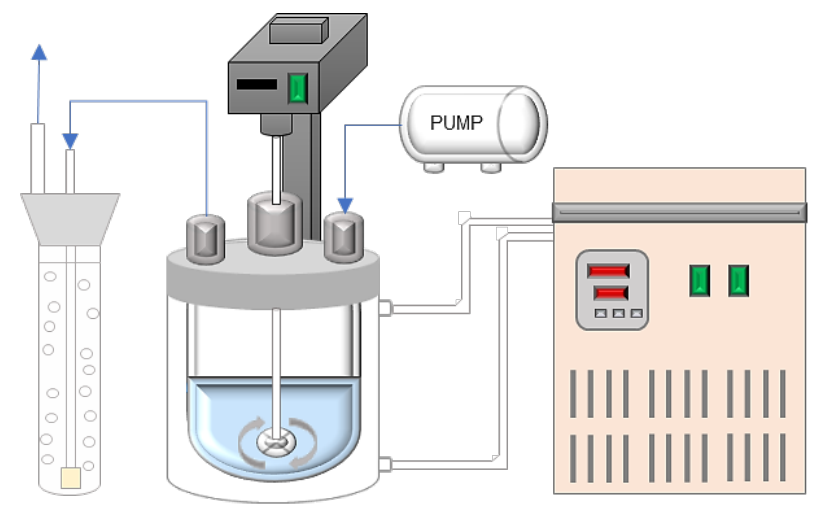

Figure 1. Schematic diagram of leaching-scrubbing system.

\section{Results and Discussion}

Table 5 summarize the leaching test results of Series I and Series II. The tests are discussed in the following sections. The tests (1 to 10) were carried out in duplicate.

Table 5. Serie I (Leach time $94 \mathrm{~h}$, and Serie II (Leach time $46 \mathrm{~h}$ ). Leaching test results in seawater.

\begin{tabular}{|c|c|c|c|c|c|c|c|c|c|}
\hline Series & $\begin{array}{l}\text { Test } \\
\mathbf{N}^{\circ}\end{array}$ & $\begin{array}{c}\text { Particle } \\
\text { Size }(\mu \mathrm{m})\end{array}$ & $\begin{array}{c}\text { Temperature } \\
\left({ }^{\circ} \mathrm{C}\right)\end{array}$ & $\begin{array}{c}{\left[\mathrm{H}_{2} \mathrm{SO}_{4}\right]} \\
\quad(\mathrm{M})\end{array}$ & $\begin{array}{l}{\left[\mathrm{NaNO}_{3}\right]} \\
(\mathrm{M})\end{array}$ & $\begin{array}{c}\text { ORP } \\
\text { Range } \\
\text { (mV vs. } \\
\text { Ag/AgCl) }\end{array}$ & $\begin{array}{l}\text { Cu Ext. } \\
\text { (wt. \%) }\end{array}$ & $\begin{array}{c}\text { Cu Ext. } \\
\text { (wt. \%) } \\
\text { (Duplicate) }\end{array}$ & $\begin{array}{c}\text { Cu Ext. } \\
\text { (wt. \%) } \\
\text { Average }\end{array}$ \\
\hline \multirow{4}{*}{ I } & 1 & -60.66 & Room & 0.1 & 0.1 & $380-463$ & 11.5 & 11.4 & 11.5 \\
\hline & 2 & -60.66 & Room & 0.1 & 0.5 & $390-760$ & 27.6 & 27.0 & 27.3 \\
\hline & 3 & -60.66 & Room & 0.5 & 0.1 & $410-793$ & 46.1 & 47.7 & 46.9 \\
\hline & 6 & -60.66 & Room & 0.5 & 0 & $435-660$ & 41.2 & 39.2 & 40.2 \\
\hline \multirow{4}{*}{ II } & 7 & -29.80 & 45 & 0.5 & 0.5 & $742-801$ & 87.5 & 89.5 & 88.5 \\
\hline & 8 & -29.80 & Room & 0.5 & 0.5 & $615-750$ & 66.7 & 66.1 & 66.0 \\
\hline & 9 & -60.66 & 45 & 0.5 & 0.5 & $743-764$ & 91.1 & 90.6 & 90.8 \\
\hline & 10 & -60.66 & Room & 0.5 & 0.5 & $751-787$ & 71.2 & 73.9 & 72.5 \\
\hline
\end{tabular}

\subsection{Series I. Leaching Test Results at Room Temperature}

\subsubsection{Variation of Redox Potential (ORP)}

Figure 2 shows the variations of the oxidation redox potential (ORP) according to leaching time. It is clear that redox potential increases when the dissolution of copper increases (see Tests 2 and 3, at 56 and $26 \mathrm{~h}$, respectively).

The results of tests 2 and 3 indicate that ion oxidation increases with higher levels of aciditsiy in the solution due to $\mathrm{NO}_{x}$ formation as an oxidant. $\mathrm{NO}_{x}$ gas did not form immediately, but was observed with extending leaching time. Once the $\mathrm{NO}_{\mathrm{x}}$ is formed, this gas tends to oxidize rapidly due to the action of the injected oxygen, turning into a brown gas, which is characteristic of $\mathrm{NO}_{2(\mathrm{~g})}$. The potential remained above $700 \mathrm{mV}$ vs. $\mathrm{Ag} / \mathrm{AgCl}$, facilitating the leaching of chalcopyrite.

The redox potential of Test 1 with $0.1 \mathrm{M} \mathrm{H}_{2} \mathrm{SO}_{4}-0.1 \mathrm{M} \mathrm{NaNO}_{3}$ solution remained low, between 400 and $450 \mathrm{mV}$ vs. $\mathrm{Ag} / \mathrm{AgCl}$, indicating a low level of chalcopyrite oxidation under these conditions. When 1.0 and $0.5 \mathrm{M}$ of acid and $0.5 \mathrm{M}$ of $\mathrm{NaNO}_{3}$ were added to the leaching solution the redox potential remained above $700 \mathrm{mV}$ vs. $\mathrm{Ag} / \mathrm{AgCl}$ throughout tests 4 and 5 enhancing the dissolution of copper. 


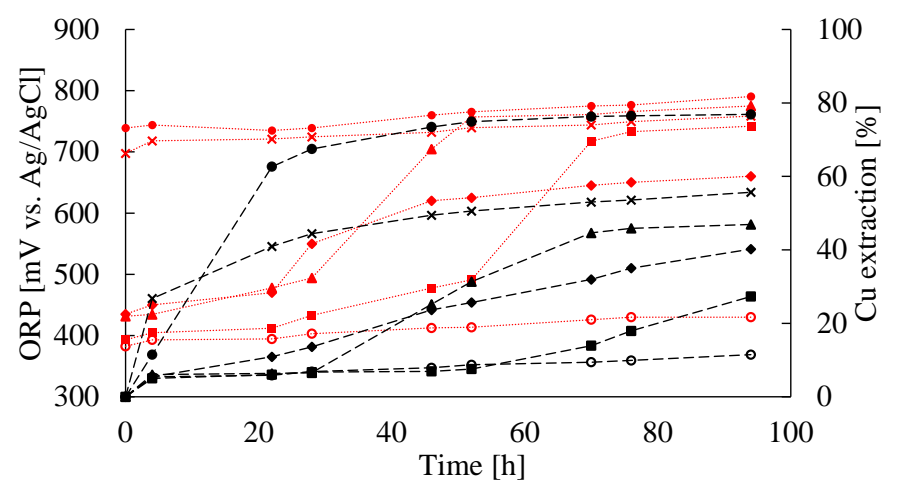

Figure 2. Dissolution of copper (\%) from chalcopyrite concentrate and averaged ORP (mV vs. Ag/AgCl) values over time (hours) for Series I at different concentrations of $\mathrm{H}_{2} \mathrm{SO}_{4}$ and $\mathrm{NaNO}_{3}$. (○) Test 1 $\left(\mathrm{H}_{2} \mathrm{SO}_{4}=0.1 \mathrm{M}\right.$ and $\left.\mathrm{NaNO}_{3}=0.1 \mathrm{M}\right) ;(\boldsymbol{\square})$ Test $2\left(\mathrm{H}_{2} \mathrm{SO}_{4}=0.1 \mathrm{M}\right.$ and $\left.\mathrm{NaNO}_{3}=0.5 \mathrm{M}\right) ;(\boldsymbol{\Lambda})$ Test $3\left(\mathrm{H}_{2} \mathrm{SO}_{4}\right.$ $=0.5 \mathrm{M}$ and $\left.\mathrm{NaNO}_{3}=0.1 \mathrm{M}\right) ;(\bullet)$ Test $4\left(\mathrm{H}_{2} \mathrm{SO}_{4}=0.5 \mathrm{M}\right.$ and $\left.\mathrm{NaNO}_{3}=0.5 \mathrm{M}\right) ;(\mathrm{X})$ Test $5\left(\mathrm{H}_{2} \mathrm{SO}_{4}=\right.$ $1.0 \mathrm{M}$ and $\left.\mathrm{NaNO}_{3}=0.1 \mathrm{M}\right) ;(\diamond)$ Test $6\left(\mathrm{H}_{2} \mathrm{SO}_{4}=0.5 \mathrm{M}\right.$ and $\left.\mathrm{NaNO}_{3}=0 \mathrm{M}\right)$. (Test conditions: $94 \mathrm{~h}$, $\mathrm{P} 80=60.66 \mu \mathrm{m}, 450 \mathrm{rpm}$ and room temperature). The copper recoveries are showing with black dotted line in axis secondary and averaged ORP values are showing with red dotted line.

\subsubsection{Effect of the Nitrate Concentration}

The influence of nitrate ion concentrations on copper extraction was investigated at room temperature. Figure 2 shows the effect of the addition of initial $\mathrm{NaNO}_{3}$ concentration. Copper extraction in solutions with $0.1 \mathrm{M}$ of $\mathrm{H}_{2} \mathrm{SO}_{4}$ increased from $11.5 \%$ to $27.3 \%$ when the concentration of $\mathrm{NaNO}_{3}$ increased from $0.1 \mathrm{M}$ (Test 1) to $0.5 \mathrm{M}$ (Test 2). The dissolution of copper leached in a solution

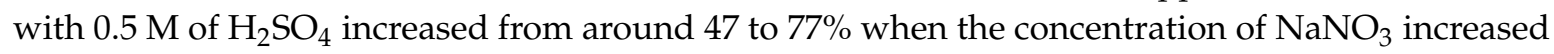
from $0.1 \mathrm{M}$ (Test 3) to $0.5 \mathrm{M}$ (Test 4). This result agree with other found in literature [4] and shows that nitrates with a standard potential of $0.96 \mathrm{~V}$ are a powerful oxidants.

\subsubsection{Effect of Sulfuric Acid Concentration}

Figure 3a shows the results of leaching copper concentrate at different concentration of acid and sodium nitrate. The dissolution of copper clearly is affected by the initial addition of both sulfuric acid and sodium nitrate concentrations to the leaching solutions. Copper extraction clearly increased with higher acid concentration (Tests 1, 3 and 5). Without enough $\mathrm{H}^{+}$ions in the system (Test 1 ), copper extraction was negligible (10-11.5\%). The experiments also showed little or no effect of sodium nitrate on copper recovery under the conditions studied (Test 1$)$.

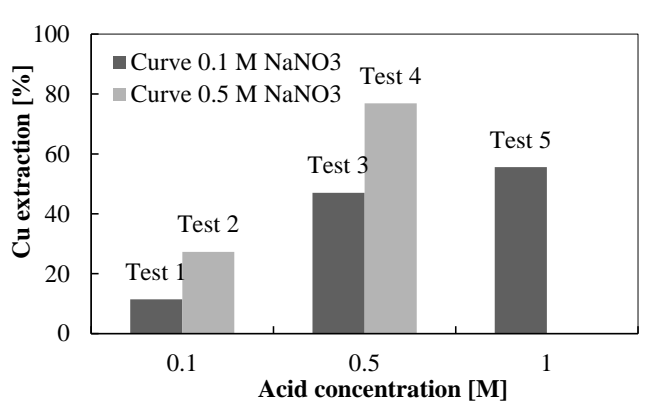

(A)

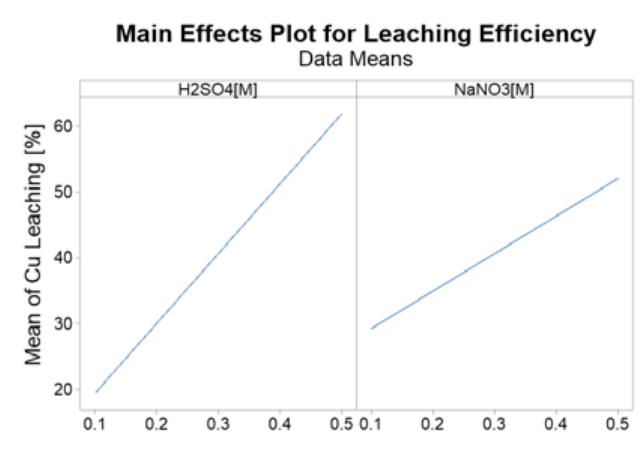

(B)

Figure 3. (A) Effect of the acid concentration on the extend of the copper concentrate at room temperature and (B) Effect of concentrations of $\mathrm{H}_{2} \mathrm{SO}_{4}$ and $\mathrm{NaNO}_{3}$ on the leaching efficiency of copper concentrate.

The copper extraction rate in Test 5, with a high acid and low sodium nitrate content, was $55.7 \%$. Although the low concentration of the oxidant the potential reminds high. This could be due to 
the formation of a new oxidant in the $\mathrm{NO}_{\mathrm{x}}$ system (perhaps $\mathrm{Fe}^{3+}$ according with Figure 7), but less powerful than $\mathrm{NaNO}_{3}$.

As shown in Figure 3A, the best copper extraction rate (76.9\%) was obtained in Test 4, with a solution containing sulfuric acid and sodium nitrate both at a concentration of $0.5 \mathrm{M}$. These highlights, presented in Figure 3B, shown the importance of the role of the concentration of $\mathrm{H}^{+}$ions compared to that of the sodium nitrate (Tests 1-3 and Tests 2-4). However, increasing amount of nitrate ion concentration enhances the copper extraction rate for all acid concentration used in the leaching solution. These results are agreed with results from Hernández et al. [11].

Table 6 shows the effect of parameters $\left(\mathrm{H}_{2} \mathrm{SO}_{4}\right.$ and $\left.\mathrm{NaNO}_{3}\right)$ using the analysis of variance (ANOVA) module of the Minitab 19 software (version 19, Pennsylvania State University, State College, PA, USA). According to Table 6, $\mathrm{H}_{2} \mathrm{SO}_{4}$ had the largest contribution (65.45\%) for copper extraction compared to $\mathrm{NaNO}_{3}$ with $32.6 \%$ approximately.

Table 6. Analysis of variance (ANOVA) for Cu extraction.

\begin{tabular}{cccccc}
\hline Parameters & Degree Freedom & Sum of Squares & Contribution & Media of Squares & Fisher Ratio \\
\hline $\mathrm{H}_{2} \mathrm{SO}_{4}$ & 2 & 1683.50 & $65.45 \%$ & 1137.21 & 22.56 \\
$\mathrm{NaNO}_{3}$ & 2 & 838.34 & $32.59 \%$ & 419.17 & 8.32 \\
Error & & 50.41 & $1.96 \%$ & 50.41 & \\
Total & & 2572.25 & $100.00 \%$ & & \\
\hline
\end{tabular}

The data of Tests 3-5, showed in Figure 2, also showed that dissolution rates slowed down in the final stage of the leaching. This is thought to be due to a formation of a layer of sulfur on the chalcopyrite particles surface (cf. Figure 4a,b). The morphology of the layer shows irregular grains with porosity that perhaps allows the solution to flow into the particles of chalcopyrite. This suggests that dissolution reaction is initially controlled by a surface mechanism, and later by diffusion reaction mechanism [16]. The extent of sulfur formation was influenced by reagent concentrations and the leaching conditions.
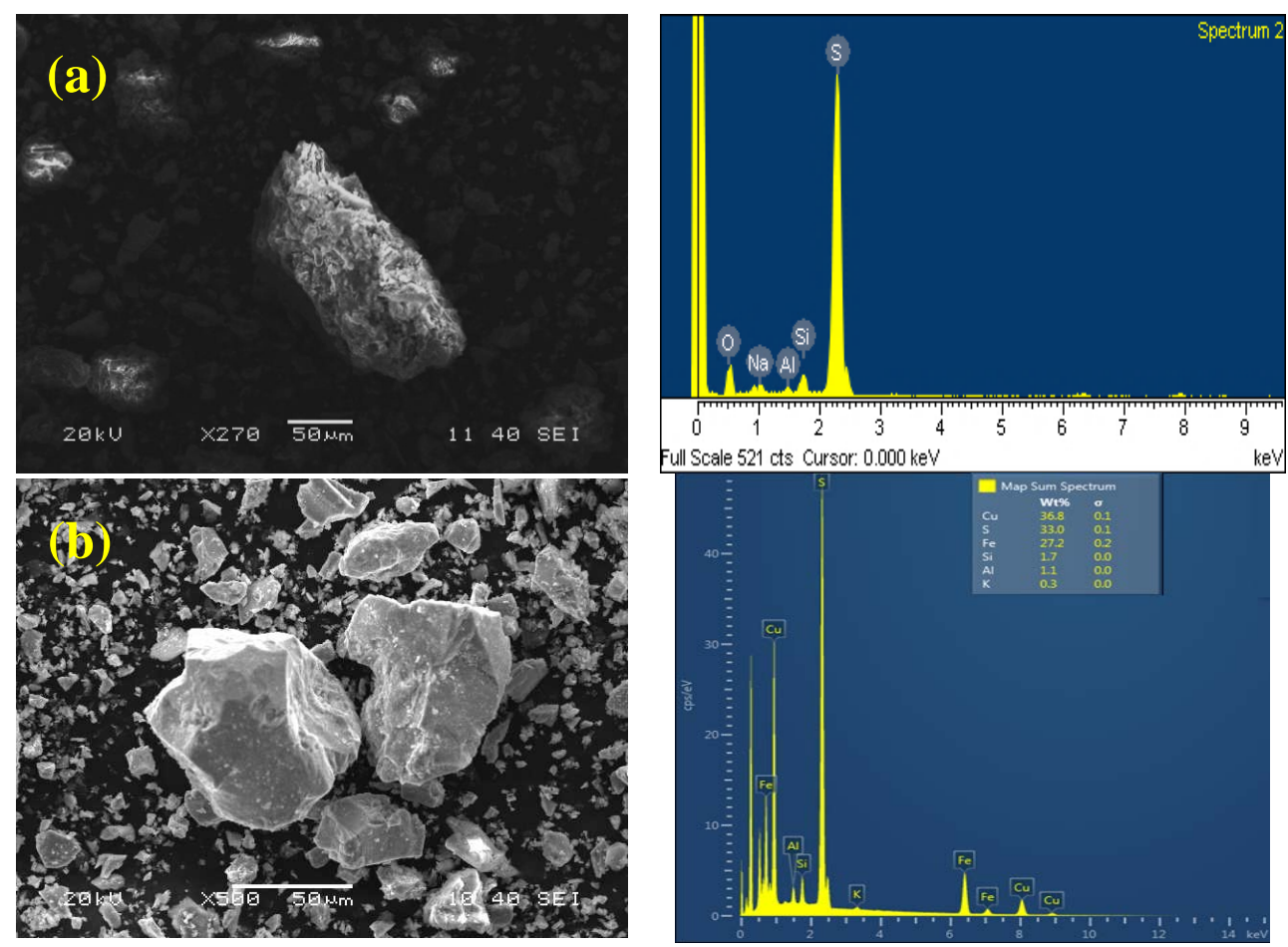

Figure 4. SEM micrographs and EDS spectrums of (a) residue (Test 4) and (b) Initial chalcopyrite concentrate sample. 


\subsection{Series II. The Effect of Temperature and Particle Size on the Leaching Rate}

The effects of increase temperature and particle size on the dissolution of copper Tests 7 to 10 of Series II (Table 5). It is not surprising that the leaching rate increases as the temperature increases from room temperature (tests 8 and 10) to $45^{\circ} \mathrm{C}$ (Tests 7 and 9) seen in Figure 5. Extraction was relatively rapid at both temperatures during the first $24 \mathrm{~h}\left(80 \%\right.$ and $60 \%$ of copper extraction at $45^{\circ} \mathrm{C}$ and room temperature respectively), but then slowed down, which was related to the formation of a thin sulfur layer on the chalcopyrite surface grains as shows in Figure 4a (see Section 3.2.1).

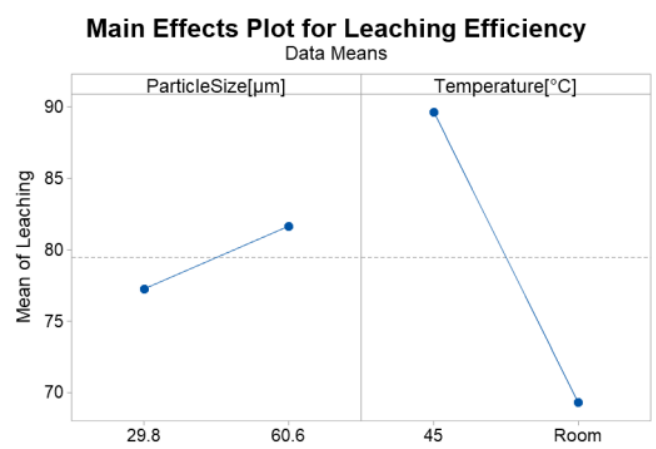

Figure 5. The effect of particle size and temperature on leaching efficiency of copper concentrate.

It seems that particle sizes between 29.8 and $60.66 \mu \mathrm{m}$ have a negligible effect on the leaching of chalcopyrite under all conditions studied, according to Table 5. All ORP values (Series II) were over $700 \mathrm{mV}$ vs. $\mathrm{Ag} / \mathrm{AgCl}$. This was due to the presence of relatively high concentrations $(0.5 \mathrm{M})$ of $\mathrm{NaNO}_{3}$ and $\mathrm{H}_{2} \mathrm{SO}_{4}$. It also shows that the ORP of finer particle size ore takes longer to reach $700 \mathrm{mV}$ when leaching is carried out at room temperature (Test 8).

\subsubsection{Characterization of the Residues}

The solid leaching residue at $45^{\circ} \mathrm{C}$, with a $\mathrm{P}_{80}$ of $60.66 \mu \mathrm{m}$ (Test 9) was characterized by XRD (Table 7) and SEM-EDS analyses. Results are shown in Figure 6.

Table 7. Mineral composition of the residue (Test 9).

\begin{tabular}{ccc}
\hline Mineral & Formula & (wt.\%) \\
\hline Chalcopyrite & $\mathrm{CuFeS}_{2}$ & 5.9 \\
Quartz & $\mathrm{SiO}_{2}$ & 11.5 \\
Sulfur & $\mathrm{S}$ & 46.3 \\
Chlorite & $(\mathrm{Mg}, \mathrm{Fe})_{6}\left(\mathrm{Si}, \mathrm{Al}_{4} \mathrm{O}_{10}(\mathrm{OH})_{8}\right.$ & 1.5 \\
Albite & $\mathrm{NaAlSi}_{3} \mathrm{O}_{8}$ & 7.7 \\
Orthoclase & $\mathrm{KAlSi}_{3} \mathrm{O}_{8}$ & 7.9 \\
Gypsum & $\mathrm{CaSO}_{4} \cdot 2 \mathrm{H}_{2} \mathrm{O}$ & 3.1 \\
Goethite & $\mathrm{FeO} \mathrm{OH})$ & 2.2 \\
Biotite & $\mathrm{KMg}_{3}\left(\mathrm{Si}_{3} \mathrm{Al}\right) \mathrm{O}_{10}(\mathrm{OH})_{2}$ & 11.8 \\
Langbeinite & $\mathrm{K}_{2} \mathrm{Mg}_{2}\left(\mathrm{SO}_{4}\right)_{3}$ & 2.1 \\
\hline
\end{tabular}

Table 7 shows the mineral phases in the leaching residue identified by XRD, indicating the presence mainly of elemental sulfur (46\%) and gangue minerals (46\%), with $5.9 \%$ of unleached chalcopyrite. The presence of large quantities of sulfur confirms the expectation that elemental sulfur forms during the leaching. The presence of sulfur is also confirmed by SEM and EDS spectra, as shown in Figure 6. This residue was selected to analyze the products formed due to the highest extraction of copper. The spectrum and the micrograph corroborated the presence of a sulfur layer on the chalcopyrite surface. The grains of sulfur have intergranular porosity. This porosity decreases with the leaching progress. The data also shows that other major sulfide minerals were completely dissolved in the first 
$48 \mathrm{~h}$. It is noted also the absence of pyrite, sphalerite and molybdenite in the residue (see Table 7), as compared to the feed material (chalcopyrite concentrate) shown in Table 4.
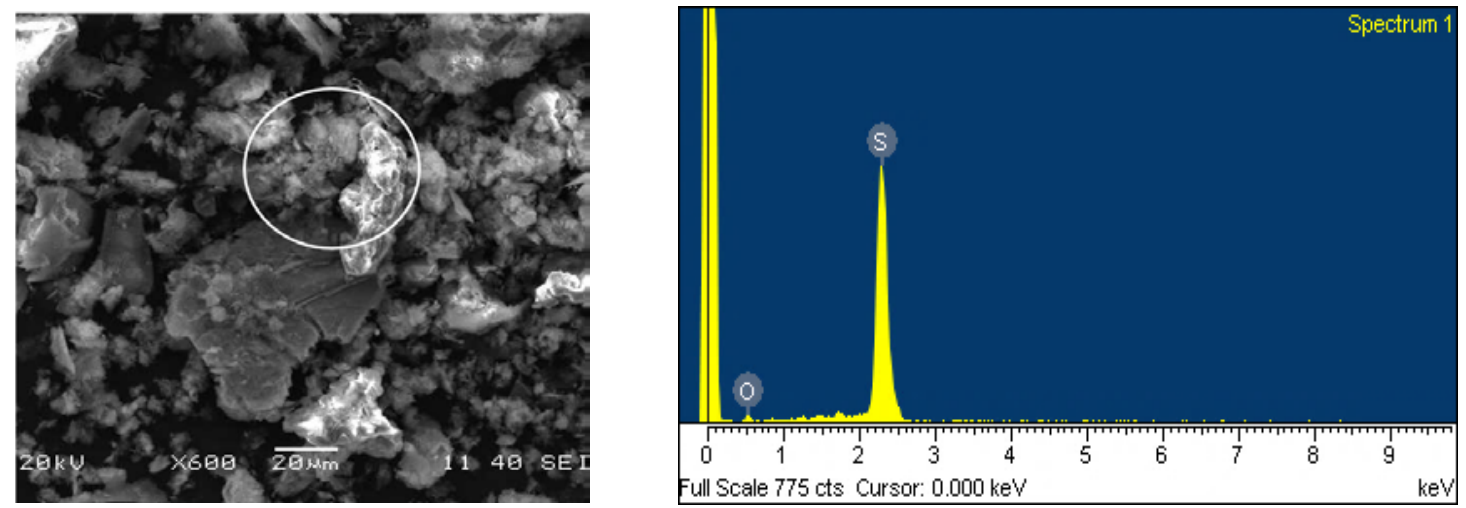

Figure 6. SEM micrograph and EDS spectrum of residue (Test 9).

In order to confirm that pyrite could leach under the studied conditions, a pure sample of pyrite $\left(\mathrm{P}_{80}=60.66 \mu \mathrm{m}\right)$ was leached with $0.5 \mathrm{M}$ of $\mathrm{H}_{2} \mathrm{SO}_{4}$ and $0.5 \mathrm{M}$ of $\mathrm{NaNO}_{3}$, the result showed that the entire pyrite sample was leached. According to thermodynamic calculations $\mathrm{NO}^{3-}$ ions and the acidity allow $\mathrm{Fe}^{3+}$ to remain in the solution and therefore acts as an oxidant. At higher ORP (600-800 $\mathrm{mV}$ vs. $\mathrm{Ag} / \mathrm{AgCl}$ ) according to the Eh-pH diagram (Figure 7) the $\mathrm{Fe}^{2+}$ then could re-oxidize to $\mathrm{Fe}^{3+}$.

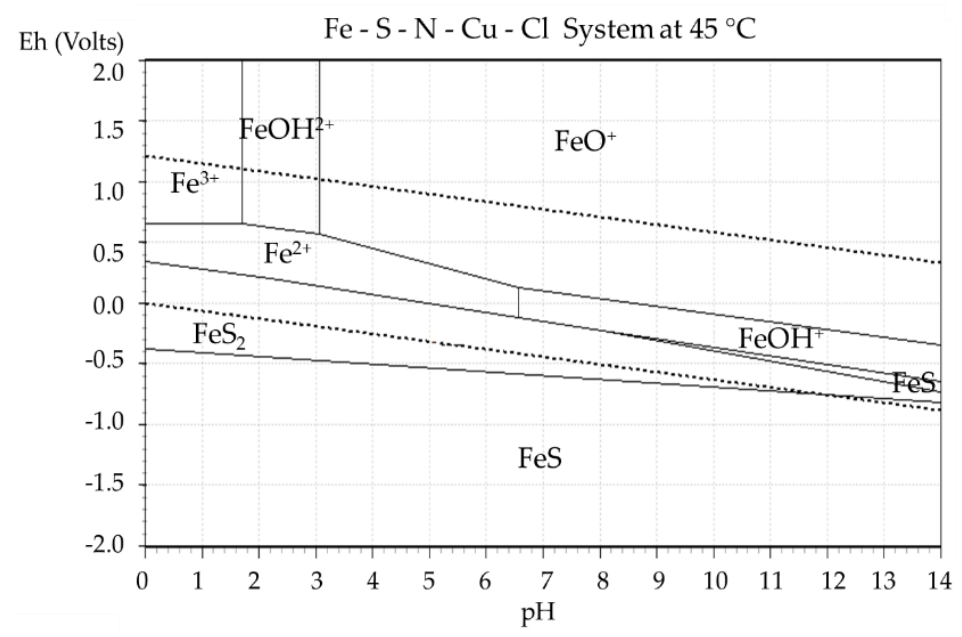

Figure 7. Diagram Eh-pH of Fe-S-N-Cu-Cl at $45{ }^{\circ} \mathrm{C}$, during the interaction of chalcopyrite concentrate (pyrite included) (HSC Chemistry 9.0 version).

\subsection{Flue Gas Scrubbing Tests}

Gas scrubbing was tested with a solution of sodium hydroxide. Table 8 shows the results of the analysis of the scrubbing solution before the crystallization stage.

Table 8. Chemical analysis of nitrogen oxide scrubbing tests.

\begin{tabular}{cccc}
\hline \multirow{2}{*}{$\begin{array}{c}\text { Scrubbing System } \\
\mathbf{( 1 . 0} \mathbf{M} \text { NaOH) }\end{array}$} & \multicolumn{3}{c}{ Chemical Analysis } \\
\cline { 2 - 4 } & $\begin{array}{c}\mathbf{N a}^{+} \\
(\mathbf{m g} / \mathbf{L})\end{array}$ & $\begin{array}{c}\mathbf{O H}^{-} \\
(\mathbf{m g} / \mathbf{L})\end{array}$ & $\begin{array}{c}\mathbf{N O}_{\mathbf{2}} \\
(\mathbf{m g} / \mathbf{L})\end{array}$ \\
\hline Test A & 21,200 & 2581 & 23,758 \\
Test B & 23,450 & 2374 & 23,820 \\
\hline
\end{tabular}


The amounts of $\mathrm{NaNO}_{2}$ and $\mathrm{NaNO}_{3}$ produced and of absorbed gas $\left(\mathrm{NO}_{2}(\mathrm{~g})\right)$, as shown in Table 8, were estimated with an ionic balance. The results are shown in Figures 8 and 9. The data shows a relationship between the scrubbing solution concentration and the percentage of crystallized salts. The alkaline concentration of the wash solution $(1.0 \mathrm{M} \mathrm{NaOH})$ allowed $\mathrm{NaNO}_{3}$ and $\mathrm{NaNO}_{2}$ salts to crystallize with a lower quantity of mass.

Test A

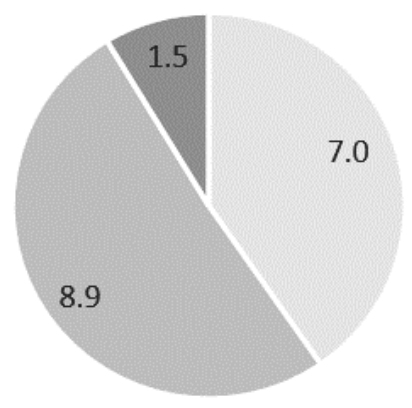

Test B

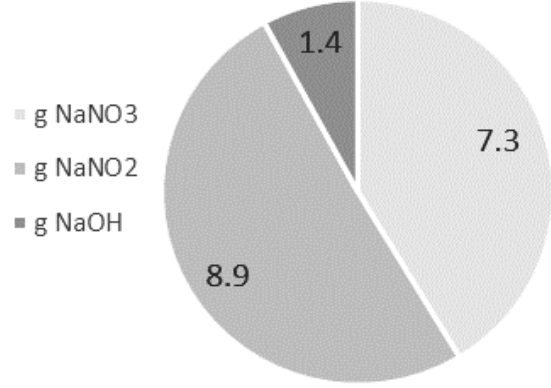

Figure 8. Amount of $\mathrm{NaNO}_{2}-\mathrm{NaNO}_{3}$ and $\mathrm{NaOH}$ salt formation (obtained from chemical analysis and ionic balance).

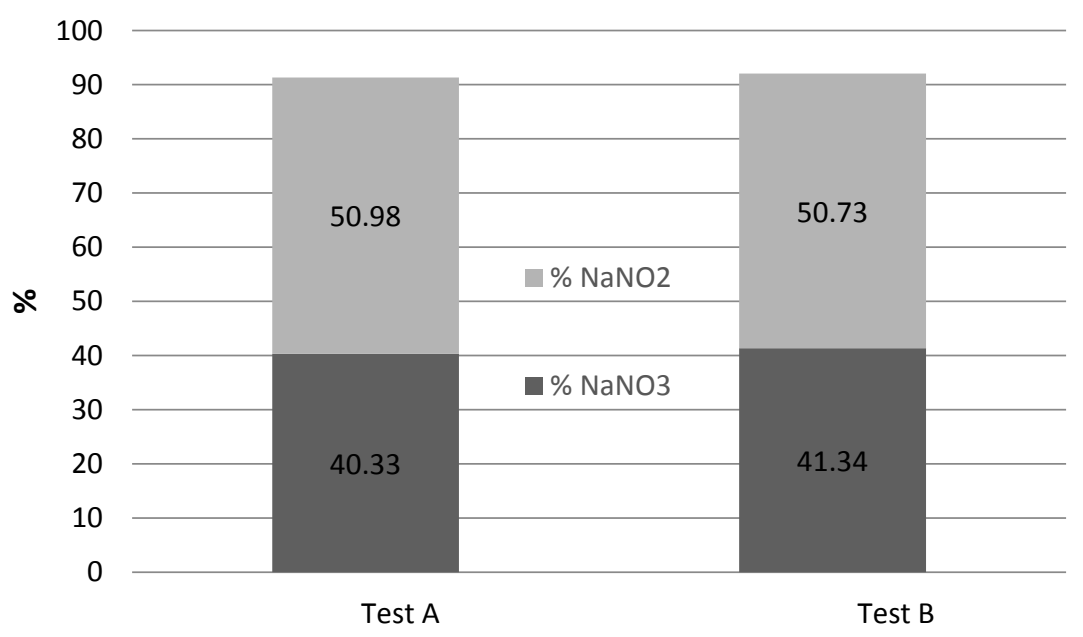

Figure 9. Percentages of $\mathrm{NaNO}_{2}-\mathrm{NaNO}_{3}$ and $\mathrm{NaOH}$ salt formed.

Differential scanning calorimetry (DSC) analyses were performed on the scrubbing systems (Tests A and B). Figures 10 and 11 shows the results of Tests A and Test B, in which the peaks occur at $228.48^{\circ} \mathrm{C}$ and $186.65^{\circ} \mathrm{C}$, respectively. These values are different from those reported by Janz et al. [34] and Janz and Tomkins [35] for pure $\mathrm{NaNO}_{2}\left(281^{\circ} \mathrm{C}\right)$ and for pure $\mathrm{NaNO}_{3}\left(307^{\circ} \mathrm{C}\right)$. The difference between the crystallized products in this study and those in the literature are related to the combination of $\mathrm{NaNO}_{2}$ and $\mathrm{NaNO}_{3}$ in the samples of this study, showing the presence of a eutectic salt as a result of absorption and crystallization by evaporation. Raman spectroscopy measurements and differential scanning calorimetry data on solidified mixtures of different compositions have provided support for a simple eutectic diagram with a solid at $230{ }^{\circ} \mathrm{C}$ ranging from 0.25 to 0.80 in mole fraction of sodium nitrate [36].

The formation of sodium and nitrogen salts is also shown (qualitatively) by SEM-EDS patterns in sample from Test A (Figure 12). The particles crystallize, as shown by EDS analysis, in small agglomerates of nitrogen salts combined with sodium. $\mathrm{NO}_{\mathbf{x}}$ gas scrubbing is a relatively complex operation that requires optimizing several parameters like the $\mathrm{NO}$ to $\mathrm{NO}_{2}$ ratio, initial concentrations, 
bubble size, temperature and the type of alkaline solution, as these parameters influence overall scrubbing efficiency.

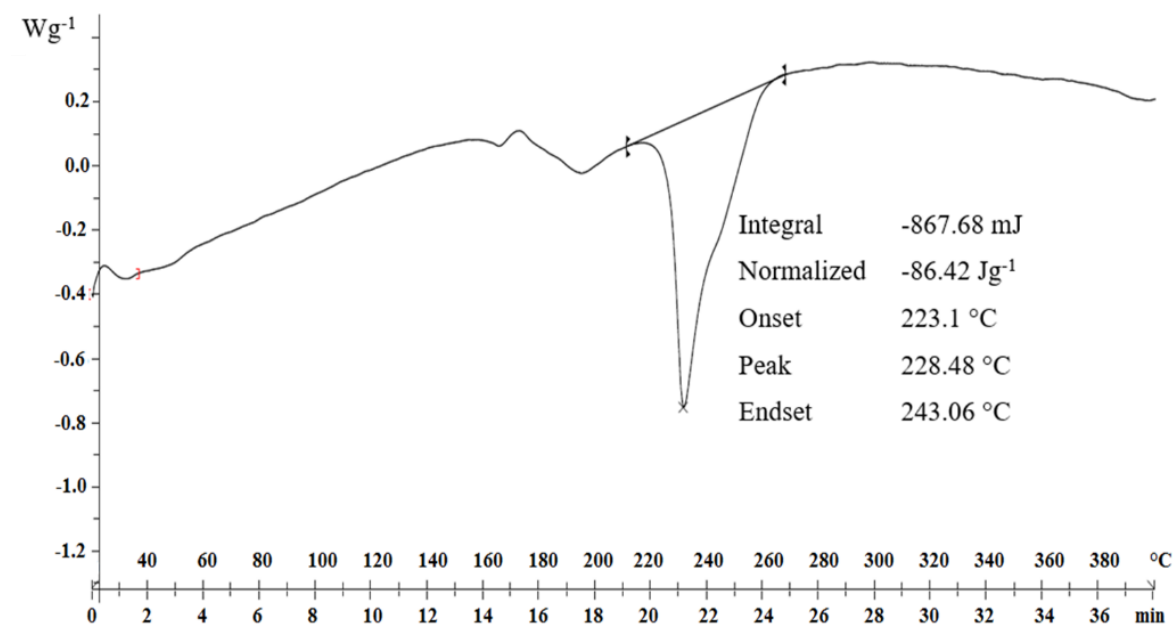

Figure 10. DSC curve for products crystallized from $\mathrm{NO}_{x}$ gases in Test $\mathrm{A}$.

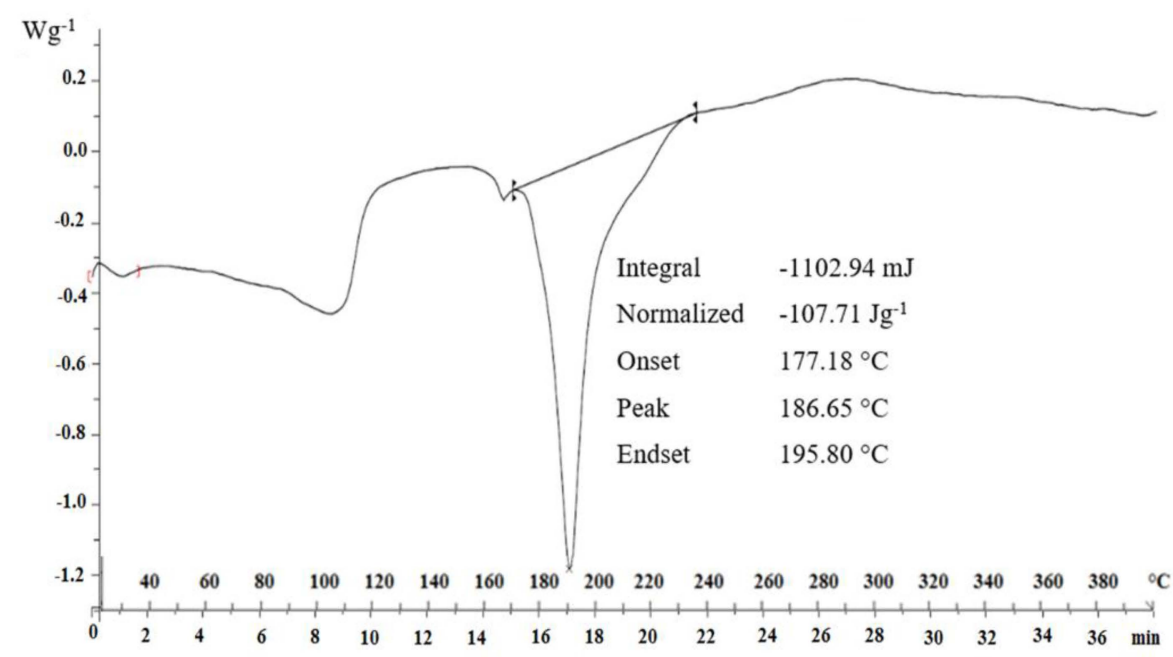

Figure 11. DSC curve for products crystallized from $\mathrm{NO}_{x}$ gases in Test $\mathrm{B}$.
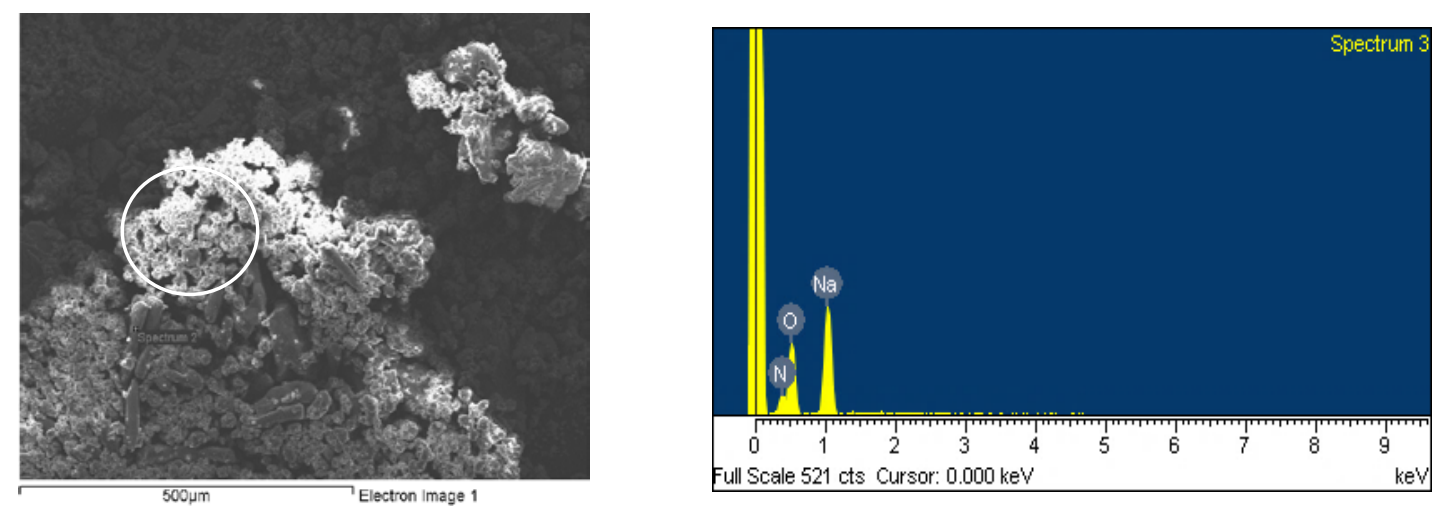

Figure 12. SEM micrograph and EDS spectrum of solids crystallized from Test A. 


\subsection{Proposed Process for Leaching Chalcopyrite and Recovering Oxidants}

This paper proposes a process for leach chalcopyrite using nitrate-acid-seawater media, with subsequent recovery and recycling of oxidant salts. The recovery of sodium nitrate and sodium nitrite from nitrous gases is also shown in the process flowsheet in Figure 13.

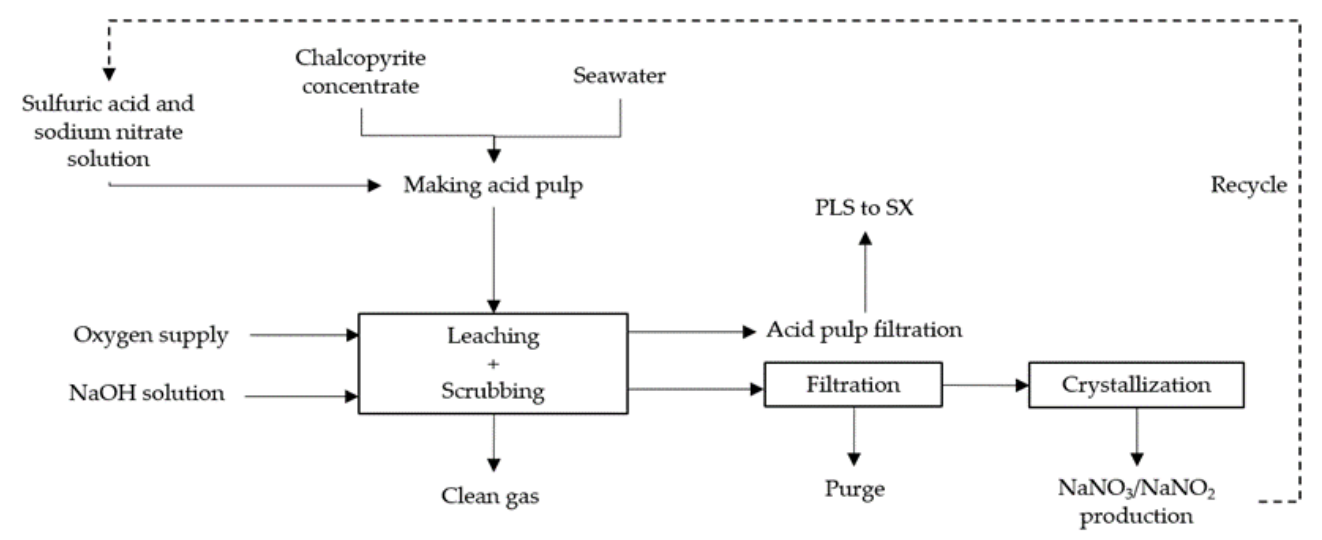

Figure 13. Proposed process for chalcopyrite leaching.

The process includes leaching, absorption and crystallization. Leaching should be carried out in closed reactors with controlled agitation to ensure continuous solid-liquid contact. The pregnant leaching solution (PLS) will continue with solvent extraction (SX) and electrowinning (EW) stages. It should be noted that there are reagents that have been created and are capable of extracting copper from a matrix with a high concentration of nitrate and chloride ions [37-42]. The second nitrous gas absorption stage recovers contaminating gases $\left(\mathrm{NO}_{\mathrm{x}}\right)$ formed by dissolving the concentrate that would otherwise escape into the environment. The last stage involves recovering salts for reusing, which can be carried out by crystallization, or by returning the absorption solution in the case of an acid or neutral absorbent.

\section{Conclusions}

Leaching of a chalcopyrite concentrate using sulfuric acid and sodium nitrate in seawater was studied. The results of this study suggest that sodium nitrate in the presence of seawater is an effective oxidation agent that makes it possible to replace other lixiviants and recovery copper faster.

The highest copper extraction of $91 \%$ was obtained when the chalcopyrite concentrate with a $\mathrm{P}_{80}$ of $60.66 \mu \mathrm{m}$ was leached with $0.5 \mathrm{M} \mathrm{H}_{2} \mathrm{SO}_{4}$ and $0.5 \mathrm{M} \mathrm{NaNO}_{3}$ at $45^{\circ} \mathrm{C}$ for a period of $46 \mathrm{~h}$.

This study shows that the rate of leaching of the finely ground ore concentrate is relatively fast for the first $24 \mathrm{~h}$ but then slows down. This is related to the formation of a passive layer of elemental sulfur on the chalcopyrite grains that was confirmed by XRD and SEM/EDS analysis. The analysis also showed that pyrite, sphalerite and molybdenite were completely dissolved within the first $48 \mathrm{~h}$.

Leaching of chalcopyrite concentrate with sulfuric acid and sodium nitrate generated $\mathrm{NO}$ and $\mathrm{NO}_{2}$ gases. Scrubbing parts of these gases in a sodium hydroxide solution recovered sodium nitrate and sodium nitrite. The amount of sodium nitrite recovered tended to exceed the amount of sodium nitrate. The recovery of sodium nitrate can be beneficial to an industrial-scale leaching operation processing copper concentrate.

Leaching technologies with the absorption stage described above are technically feasible and environmentally friendly. Future studies should consider improving the environmental effects of leaching and making the process more economical. These might be the recyclability of recrystallized salts and the amenability of the PLS to solvent extraction for Cu recovery. 
Author Contributions: C.I.C. contributed in research and wrote paper, P.C.H. contributed in project. L.V.-Y. and M.E.T. contributed in review and editing. All authors have read and agreed to the published version of the manuscript. All of the authors contributed to analyzing the results and writing the paper.

Funding: This research was funded by ANID-PFCHA/National Doctoral Program/2017-21171313, FONDECYT Project 11170179 and CODELCO Piensa Mineria scholarship.

Acknowledgments: César I. Castellón thanks ANID-PFCHA/National Doctoral Program/2017-21171313, Piensa Mineria scholarship from CODELCO and María E. Taboada thanks the Universidad de Antofagasta for the support provided.

Conflicts of Interest: The authors declare no conflict of interest.

\section{References}

1. Li, Y.; Kawashima, N.; Li, J.; Chandra, A.; Gerson, A.R. A review of the structure, and fundamental mechanisms and kinetics of the leaching of chalcopyrite. Adv. Colloid Interface Sci. 2013, 197, 1-32. [CrossRef]

2. Velásquez-Yévenes, L.; Nicol, M.; Miki, H. The dissolution of chalcopyrite in chloride solutions: Part 1. The effect of solution potential. Hydrometallurgy 2010, 103, 108-113. [CrossRef]

3. Nicol, M.; Miki, H.; Velásquez-Yévenes, L. The dissolution of chalcopyrite in chloride solutions: Part 3. Mechanisms. Hydrometallurgy 2010, 103, 86-95. [CrossRef]

4. Watling, H. Chalcopyrite hydrometallurgy at atmospheric pressure: 1. Review of acidic sulfate, sulfate-chloride and sulfate-nitrate process options. Hydrometallurgy 2013, 140, 163-180. [CrossRef]

5. McDonald, R.; Muir, D. Pressure oxidation leaching of chalcopyrite. Part I. Comparison of high and low temperature reaction kinetics and products. Hydrometallurgy 2007, 86, 191-205. [CrossRef]

6. Romero, R.; Mazuelos, A.; Palencia, I.; Carranza, F. Copper recovery from chalcopyrite concentrates by the BRISA process. Hydrometallurgy 2003, 70, 205-215. [CrossRef]

7. Watling, H. Chalcopyrite hydrometallurgy at atmospheric pressure: 2. Review of acidic chloride process options. Hydrometallurgy 2014, 146, 96-110. [CrossRef]

8. Gok, O.; Anderson, C.G. Dissolution of low-grade chalcopyrite concentrate in acidified nitrite electrolyte. Hydrometallurgy 2013, 134-135, 40-46. [CrossRef]

9. Cisternas, L. Uso de Agua de mar en la mineria. Fundamentos y Aplicaciones; RIL Editores: Santiago, Chile, 2014.

10. Torres, C.; Taboada, M.; Graber, T.; Herreros, O.; Ghorbani, Y.; Watling, H. The effect of seawater based media on copper dissolution from low-grade copper ore. Miner. Eng. 2015, 71, 139-145. [CrossRef]

11. Hernández, P.C.; Taboada, M.E.; Herreros, O.O.; Graber, T.A.; Ghorbani, Y. Leaching of Chalcopyrite in Acidified Nitrate Using Seawater-Based Media. Minerals 2018, 8, 238. [CrossRef]

12. Hernández, P.; Taboada, M.; Herreros, O.; Torres, C.; Ghorbani, Y. Chalcopyrite dissolution using seawater-based acidic media in the presence of oxidants. Hydrometallurgy 2015, 157, 325-332. [CrossRef]

13. Velásquez-Yévenes, L.; Quezada-Reyes, V. Influence of seawater and discard brine on the dissolution of copper ore and copper concentrate. Hydrometallurgy 2018, 180, 88-95. [CrossRef]

14. Hernández, P.C.; Dupont, J.; Herreros, O.O.; Jimenez, Y.P.; Torres, C.M. Accelerating copper leaching from sulfide ores in acid-nitrate-chloride media using agglomeration and curing as pretreatment. Minerals 2019, 9, 250. [CrossRef]

15. Stetefeldt, G.A. Process of Treating Sulphides. U.S. Patent 287,737, 30 October 1883.

16. Sokić, M.D.; Marković, B.; Živković, D. Kinetics of chalcopyrite leaching by sodium nitrate in sulphuric acid. Hydrometallurgy 2009, 95, 273-279. [CrossRef]

17. Pacovic, N.V. Hydrometalurgy SRIF; Bor, Serbia, 1980; Chapter 3.

18. Vračar, R.Ž.; Vučković, N.; Kamberović, Ž. Leaching of copper (I) sulphide by sulphuric acid solution with addition of sodium nitrate. Hydrometallurgy 2003, 70, 143-151. [CrossRef]

19. Sokić, M.D.; Matković, V.L.; Marković, B.R.; Štrbac, N.D.; Živković, D.T. Passivation of chalcopyrite during the leaching with sulphuric acid solution in presence of sodium nitrate. Hem. Ind. 2010, 64, 343-350.

20. Sokić, M.; Radosavljević, S.; Marković, B.; Matković, V.; Štrbac, N.; Kamberović, Ž.; Živković, D. Influence of chalcopyrite structure on their leaching by sodium nitrate in sulphuric acid. Metall. Mater. Eng. 2014, 20, 53-60. [CrossRef]

21. Bredenhann, R.; Van Vuuren, C. The leaching behaviour of a nickel concentrate in an oxidative sulphuric acid solution. Miner. Eng. 1999, 12, 687-692. [CrossRef] 
22. Linnow, K.; Steiger, M.; Lemster, C.; De Clercq, H.; Jovanović, M. In situ Raman observation of the crystallization in $\mathrm{NaNO}_{3}-\mathrm{Na}_{2} \mathrm{SO}_{4}-\mathrm{H}_{2} \mathrm{O}$ solution droplets. Environ. Earth Sci. 2013, 69, 1609-1620. [CrossRef]

23. Rodriguez-Navarro, C.; Doehne, E.; Sebastian, E. How does sodium sulfate crystallize? Implications for the decay and testing of building materials. Cem. Concr. Res. 2000, 30, 1527-1534. [CrossRef]

24. Suchak, N.; Joshi, J. Simulation and optimization of NOx absorption system in nitric acid manufacture. AIChE J. 1994, 40, 944-956. [CrossRef]

25. Kameoka, Y.; Pigford, R.L. Absorption of nitrogen dioxide into water, sulfuric acid, sodium hydroxide, and alkaline sodium sulfite aqueous solutions. Ind. Eng. Chem. Fundam. 1977, 16, 163-169. [CrossRef]

26. Aoki, M.; Tanaka, H.; Komiyama, H.; Inoue, H. Simultaneous absorption of $\mathrm{NO}$ and $\mathrm{NO}_{2}$ into alkaline solutions. J. Chem. Eng. Jpn. 1982, 15, 362-367. [CrossRef]

27. Carta, G. Scrubbing of nitrogen oxides with nitric acid solutions. Chem. Eng. Commun. 1986, 42, 157-170. [CrossRef]

28. Carta, G. Role of nitrous acid in the absorption of nitrogen oxides in alkaline solutions. Ind. Eng. Chem. Fundam. 1984, 23, 260-264. [CrossRef]

29. Suchak, N.J.; Jethani, K.; Joshi, J.B. Absorption of nitrogen oxides in alkaline solutions: Selective manufacture of sodium nitrite. Ind. Eng. Chem. Res. 1990, 29, 1492-1502. [CrossRef]

30. Xiao, Z.; Li, D.; Wang, F.; Sun, Z.; Lin, Z. Simultaneous Removal of $\mathrm{NO}$ and $\mathrm{SO}_{2}$ with A New Recycling Micro-nano Bubble Oxidation-absorption Process Based on HA-Na. Sep. Purif. Technol. 2020, 242, 116788. [CrossRef]

31. Joshi, J.; Mahajani, V.; Juvekar, V. Invited review absorption of NOx gases. Chem. Eng. Commun. 1985, 33, 1-92. [CrossRef]

32. Duncan, J.L.; McLarnon, C.R.; Alix, F.R. NOx, Hg, and SO2 Removal Using Ammonia. U.S. Patent 6,936,231, 30 August 2005.

33. Hignett, T.P. Fertilizer Manual; Springer Science \& Business Media: Berlin/Heidelberg, Germany, 2013; Volume 15.

34. Janz, G.J.; Ward, A.T.; Reeves, R.D. Molten Salt Data. Electrical Conductance, Density, and Viscosity; DTIC Document: Los Angeles, CA, USA, 1964.

35. Janz, G.; Tomkins, R. Molten Salts: Volume 5, Part 2. Additional Single and Multi-Component Salt Systems. Electrical Conductance, Density, Viscosity and Surface Tension Data. J. Phys. Chem. Ref. Data 1983, 12, 591-815. [CrossRef]

36. Berg, R.W.; Kerridge, D.H.; Larsen, P.H. $\mathrm{NaNO}_{2+} \mathrm{NaNO}_{3}$ phase diagram: New data from DSC and Raman spectroscopy. J. Chem. Eng. Data 2006, 51, 34-39. [CrossRef]

37. Yáñez, H.S.A.; Soderstrom, M.; Bednarski, T. Nitration in copper SX? Cytec Acorga provides a new reagent. In Hydrocopper 2009; Gecamin Ltd.: Santiago, Chile, 2009.

38. Zambra, R.Q.A.; Rivera, G.; Castro, O. Use of $\mathrm{NR}^{\circledR}$ reagents in presence of nitrate ion in SX: A revision of the present moment. In Hydroprocess 2013; Gecamin Ltd.: Santiago, Chile, 2013.

39. Hamzah, B.; Jalaluddin, N.; Wahab, A.W.; Upe, A. Copper (II) extraction from nitric acid solution with 1-phenyl-3-methyl-4-benzoyl-5-pyrazolone as a cation carrier by liquid membrane emulsion. J. Chem. 2010, 7, 239-245. [CrossRef]

40. Virnig, M.J.; Mattison, P.L.; Hein, H.C. Processes for the Recovery of Copper from Aqueous Solutions Containing Nitrate Ions. U.S. Patent 6,702,872, 22 July 2004.

41. Yáñez, H.A.; Ardiles, L.; Reyes, F.; Joly, P.; Mejias, J. Washing Stages in the Control of Chloride Transfer from Leach Solutions to the Electrolyte in Copper Solvent Extraction Process. In Hydroprocess 2018; Gecamin Ltd.: Santiago, Chile, 2018.

42. Yáñez, H.A.; Ardiles, L.; Del Río, C. High Chloride in PLS and their Impact on Copper Solvent Extraction. In Hydroprocess 2017; Gecamin Digital Publications: Santiago, Chile, 2017.

(C) 2020 by the authors. Licensee MDPI, Basel, Switzerland. This article is an open access article distributed under the terms and conditions of the Creative Commons Attribution (CC BY) license (http://creativecommons.org/licenses/by/4.0/). 